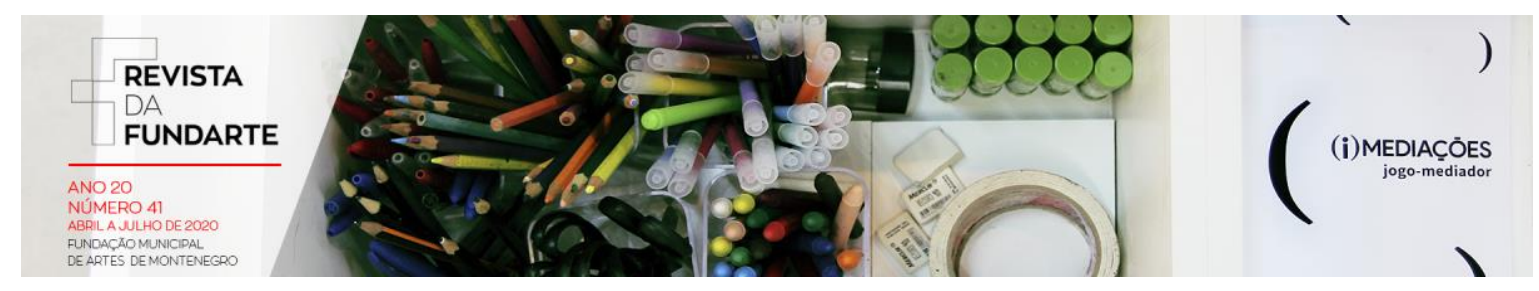

\title{
ILHAS E TENTILHÕES: O CONVÍVIO SOCIAL COMO ESTRATÉGIA DE ACESSO E INCLUSÃO EM DANÇA
}

\author{
Andrea Lucia Serio Bertoldi \\ Matheus dos Anjos Margueritte
}

DOI: http://dx.doi.org/10.19179/2F2319-0868.702

BERTOLDI, Andrea Lucia Serio; MARQUERITTE, Matheus dos Anjos. Ilhas e tentilhões: o convívio social como estratégia de acesso e inclusão em dança. Revista da FUNDARTE. Montenegro, p.0125, ano 20, no 41, Abril/Junho de 2020.

Disponível em: http://.seer.fundarte.rs.gov.br/index.php/RevistadaFundarte/index> 30 de junho de 2020. 


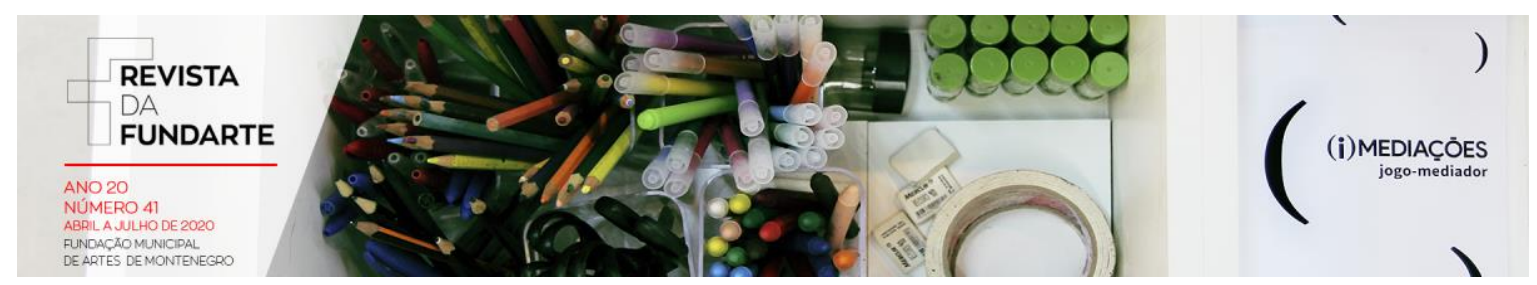

\title{
ILHAS E TENTILHÕES: O CONVÍVIO SOCIAL COMO ESTRATÉGIA DE ACESSO E INCLUSÃO EM DANÇA
}

\author{
Andrea Lucia Serio Bertoldi ${ }^{1}$ \\ Matheus dos Anjos Margueritte ${ }^{2}$
}

\begin{abstract}
Resumo: Este artigo apresenta a percepção de pessoas com deficiência, estudantes de dança e seus professores, sobre aspectos do ensino e aprendizagem da dança no contexto do ensino nãoformal de dança, especificamente em academia de dança. Foi realizado um estudo de caso de natureza qualitativa com uso de entrevista semiestruturada como instrumento de coleta de dados com 10 estudantes com deficiência neuromotora e transtornos globais de desenvolvimento e 2 professores desses estudantes. Os dados foram analisados e contextualizados a partir do conceito de umwelt, proposto por Jacob Von Uexkull, em interface com a abordagem de aprendizagem inventiva, proposta por Virginia Kastrup, aplicados à produção de conhecimento em arte/dança.
\end{abstract}

Palavras-chave: Dança; Ensino; Inclusão.

\section{ISLAND AND FINCHES: THE SOCIAL CONVIVAL AS A STRATEGY FOR ACCESS AND INCLUSION IN DANCE}

\begin{abstract}
This article presents the perception of people with disabilities, dance students and their teachers about aspects of dance teaching and learning in the context of non-formal dance education, specifically in dance academy. A qualitative case study was conducted using semi-structured interviews as a data collection instrument with 10 students with neuromotor disabilities and global developmental disorders and 2 teachers of these students. The data were analyzed and contextualized from the concept of umwelt, proposed by Jacob Von Uexkull, in interface with the approach of inventive learning, proposed by Virginia Kastrup, applied to the production of knowledge in art/dance.
\end{abstract}

Keywords: Dance; Teaching; Inclusion.

\section{Introdução}

A inclusão de pessoas com deficiência em ambientes não formais de ensino da dança, mais especificamente em academias de dança, é um processo recente,

\footnotetext{
1 Professora do Curso de Bacharelado e Licenciatura em Dança e do Programa de Pós-Graduação Mestrado Profissional em Artes PPGARTES - da Universidade Estadual do Paraná. Pesquisadora do Grupo de Pesquisa em Dança - Linha Mediações Educacionais em Dança.

2 Pesquisador do Grupo de Pesquisa em Dança da Universidade Estadual do Paraná - Unespar, Bolsista do CNPq no Programa de Iniciação Científica da Unespar.
}

BERTOLDI, Andrea Lucia Serio; MARQUERITTE, Matheus dos Anjos. Ilhas e tentilhões: o convívio social como estratégia de acesso e inclusão em dança. Revista da FUNDARTE. Montenegro, p.0125, ano 20, no 41, Abril/Junho de 2020.

Disponível em: http://.seer.fundarte.rs.gov.br/index.php/RevistadaFundarte/index> 30 de junho de 2020. 


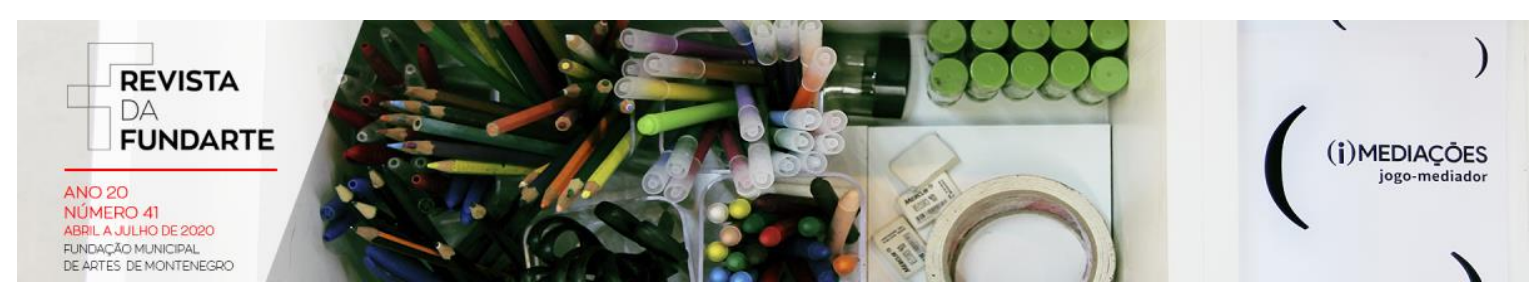

permeado de desafios que extrapolam o entendimento de acessibilidade no sentido utilitário do termo e deflagram a necessidade de aprofundamento dos contextos de análise, considerando as percepções dos atores envolvidos na interface entre inclusão/exclusão, presentes nas mediações interdependentes de ensino, aprendizagem e criação em dança.

A área da dança tem produzido trabalhos artísticos incluindo pessoas com deficiência de maneira crescente há aproximadamente 30 anos (MATOS, 2012; BERTOLDI; SOUZA, 2009). Diversos desses trabalhos demonstram a possibilidade de atuação artística dessas pessoas, evidenciando inclusive a possibilidade de profissionalização, principalmente na produção em dança contemporânea (BERTOLDI, 2015). O entendimento de que a dança é uma arte que considera a potência da singularidade dos corpos é um convite a repensarmos discursos miméticos de mecanismos de exclusão de artistas com deficiência, verificados em relações paternalistas que permeiam práticas de dança com pessoas/corpos culturalmente marginalizados diante de padrões pré-estabelecidos de normatividade dos corpos que dançam (BERTOLDI; SOUZA, 2009; MATOS, 2002, 2012).

Ainda que avanços tenham ocorrido em prol da validação e inclusão de pessoas com deficiência na produção artística da dança, observamos ainda desafios importantes a serem enfrentadas no que se refere à possibilidade de desenvolvimento dos potenciais dessas pessoas na dança, com a persistência de barreiras multidimensionais de acesso que extrapolam questões mais facilmente evidenciadas, tais como, a falta de acessibilidade arquitetônica, comuns nos espaços dedicados ao ensino da dança, e transbordam para questões de natureza epistemológica e social que expõem lacunas entre teoria e prática no campo da dança.

Este fato evidencia a complexidade do conceito de acessibilidade, entendido como condição de transposição dos entraves que representam as barreiras para a efetiva participação das pessoas com deficiência nos vários âmbitos da vida social como estratégia de acesso e inclusão em dança. Revista da FUNDARTE. Montenegro, p.0125, ano 20, no 41, Abril/Junho de 2020.

Disponível em: http://.seer.fundarte.rs.gov.br/index.php/RevistadaFundarte/index> 30 de junho de 2020. 


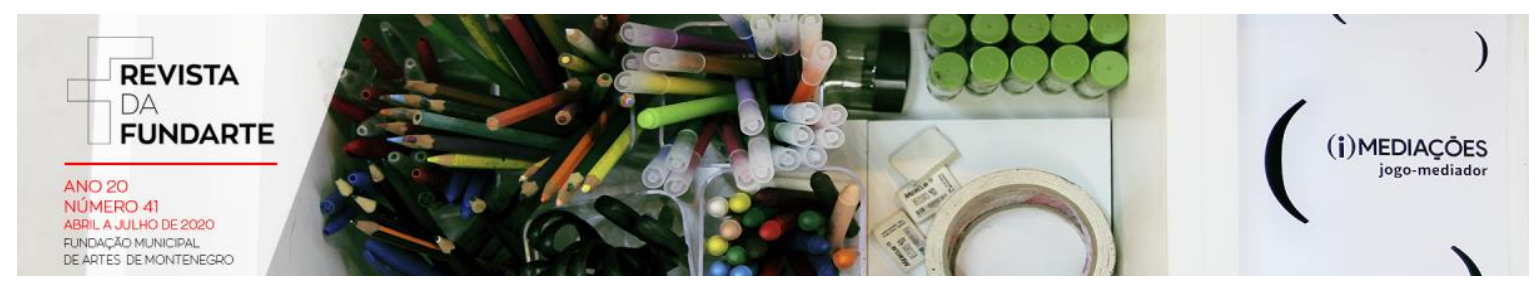

(SASSAKI, 2005) e, por vezes, reflete mecanismos de exclusão desse grupo social nas subjetividades das práxis próprias do ensino da dança.

No que compete à Educação, Reis (2016) reforça que as políticas públicas de ensino e inclusão avançaram no campo teórico, mas, ainda há lacunas no âmbito prático, sobretudo, no que se refere à capacitação dos profissionais que atuam com essa população. A característica de desconexão entre teoria e prática parece persistir em situações relacionadas ao ensino da dança, tanto em turmas compostas exclusivamente por pessoas com deficiência, quanto em situações em que há estudantes com deficiência inseridos em turmas chamadas regulares, nas quais há também estudantes sem deficiência. Ocorre, por vezes, uma espécie de quase inclusão que insiste em demonstrar que o trabalho pedagógico, apesar de centrado na diversidade, não está pautado na diferença. Na opinião de Reis (2016), o convívio social na diferença é uma oportunidade para todas as pessoas se perceberem como indivíduos multidimensionais, considerando aspectos sociais, psíquicos, biológicos e também laborais do processo educacional e artístico.

Greiner (2017), reforça a importância do convívio na diferença refletindo sobre o conceito de alteridade na arte - e aqui recortamos o olhar para a dança. A autora destaca a demanda de experiências que lidam com um estado corporal que é descontinuado naquilo que é o outro, potencializando a noção de individuação do ser humano, construída no coletivo, na fricção das interações corpo-mente-ambiente estabelecidas na presença da diferença.

A percepção das subjetividades de um dado contexto de relação entre corpo e ambiente tem sido objeto de estudo da Neurociência Cognitiva e, entre as importantes descobertas da atualidade, observa-se que o diálogo entre sensação, sentimentos e emoção integram processos de cognição e ressignificam o entendimento de consciência humana como um fenômeno corporificado (DAMÁSIO, 2011 , 2012). Vertentes da Filosofia, relacionadas às ciências cognitivas, reafirmam a interdependência entre o corpo e a percepção de realidade como, por exemplo, no social como estratégia de acesso e inclusão em dança. Revista da FUNDARTE. Montenegro, p.0125, ano 20, no 41, Abril/Junho de 2020.

Disponível em: http://.seer.fundarte.rs.gov.br/index.php/RevistadaFundarte/index> 30 de junho de 2020. 


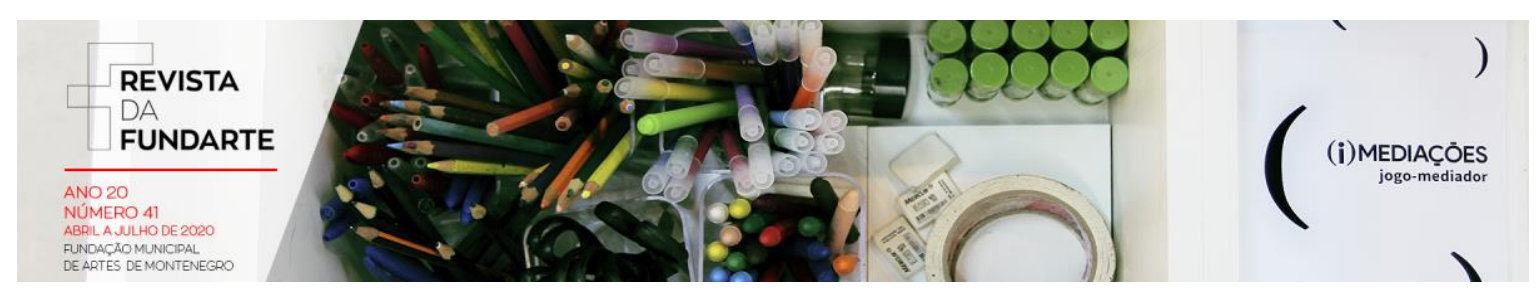

conceito de embodiment cognition, em que a noção de corporificação da mente humana é reforçada no reconhecimento do caráter motivador e interdependente da experiência corporal e a cognição, destacando o papel da subjetividade do corpo na construção do conhecimento (LAKOFF; JOHNSON, 1999).

Para Hanna e Maise (2009), a tese da consciência corporificada está vinculada à noção de expansão do entendimento de consciência de uma encarnação puramente neurobiológica nos sistemas vitais do organismo, para sua extensão aos domínios do ambiente, reafirmando a abordagem relacional do corpo como fenômeno vivo e vivido. Reforçando essa ideia, os biólogos Maturana e Varela (1995), abordam a interface entre a experiência corporal e a percepção da realidade no conceito de autopoieses. Os autores enfatizam que, embora sejamos determinados por uma estrutura biológica, essa determinação estrutural não implica num reducionismo biológico, na medida em que os modos de interação do corpo com o meio estabelecem a própria auto-organização dos sistemas corporais.

Segundo o biólogo estoniano Jacob von Uexkull, a interface entre o que se entende por realidade e o sistema vivo que a percebe é chamada de umwelt (UEXKULL, 1992). Essa interface é própria de cada espécie viva e seria absolutamente necessária para a garantir sua sobrevivência, considerando que ela é "a ponte entre a realidade objetiva e o mundo representacional de um sistema cognitivo" (VIEIRA, 2006, p. 80). Em outras palavras, é por meio da especificidade da experiência corporal, ou umwelt, que criamos percepções próprias de realidade, atravessadas pelas subjetividades que configuram, desde as percepções mais básicas de sobrevivência orgânica até a complexidade da noção de pertencimento de um sistema vivo ao contexto em que habita (HANNA; MAISE, 2009; MARINIS, 2012; DAMASIO, 2012).

Partindo do pressuposto de que a percepção da realidade é uma construção de representações, intenções, simulações e previsões da experiência vivida, dependentes das subjetividades implícitas no corpo, é importante analisar os

BERTOLDI, Andrea Lucia Serio; MARQUERITTE, Matheus dos Anjos. Ilhas e tentilhões: o convívio social como estratégia de acesso e inclusão em dança. Revista da FUNDARTE. Montenegro, p.0125, ano 20, n -41, Abril/Junho de 2020.

Disponível em: http://.seer.fundarte.rs.gov.br/index.php/RevistadaFundarte/index> 30 de junho de 2020. 


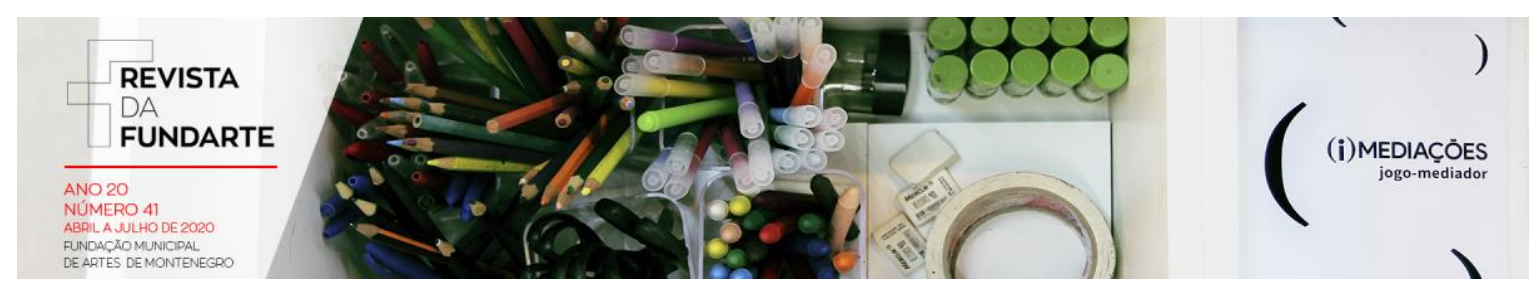

paradigmas de corpo e de dança que permeiam práticas de ensino e aprendizagem da dança incluindo corpos/pessoas com deficiência, a partir das percepções próprias dos atores envolvidos nesses processos. Para Kastrup (2005, 2012) as subjetividades individuais são, em essência, o objeto de uma aprendizagem que se manifesta na inventividade. A autora aborda o conceito de aprendizagem inventiva apresentando-o não como um método, mas, como uma política pedagógica que adota a invenção como ponto de vista para fazer frente ao processo de problematização, cerne da aprendizagem e base da produção de conhecimento humano.

Para Kastrup (2001), a aprendizagem emerge do questionamento de hábitos e padrões estabelecidos em uma realidade. Não se efetiva, portanto, no reconhecimento, mas, no exercício do estranhamento dos contextos. Essa perspectiva de aprendizagem se diferencia da mera busca por soluções de problemas postos, e reconhece a coexistência entre instabilidade e estabilidade como inerentes a comportamentos inventivos.

O pensamento que coloca a invenção e a problematização no centro do processo de aprendizagem implica também em um fazer sistematizado e organizado (KASTRUP, 2012). Porém, diferentemente de sistemas ancorados em ideias de reprodução e automatização de comportamentos, ele acolhe e valida à imprevisibilidade própria da relação corpo-ambiente no tempo presente, entendida como eixo central da concepção de um aprender e ensinar inventivos.

Dessa forma, os conceitos de consciência corporificada e aprendizagem inventiva parecem evidenciar a problematização e a invenção da realidade como potencialidades dos corpos em sua subjetividade e diversidade. Essa visão abre um amplo caminho de investigação e análise dos contextos de ensino, aprendizagem e criação em dança com uma perspectiva pedagógica inclusiva. Diante do exposto, este estudo investigou como estudantes de dança com deficiência e seus professores percebem o contexto de suas práticas no ambiente do ensino não-

BERTOLDI, Andrea Lucia Serio; MARQUERITTE, Matheus dos Anjos. Ilhas e tentilhões: o convívio social como estratégia de acesso e inclusão em dança. Revista da FUNDARTE. Montenegro, p.0125, ano 20, no 41, Abril/Junho de 2020.

Disponível em: http://.seer.fundarte.rs.gov.br/index.php/RevistadaFundarte/index> 30 de junho de 2020. 


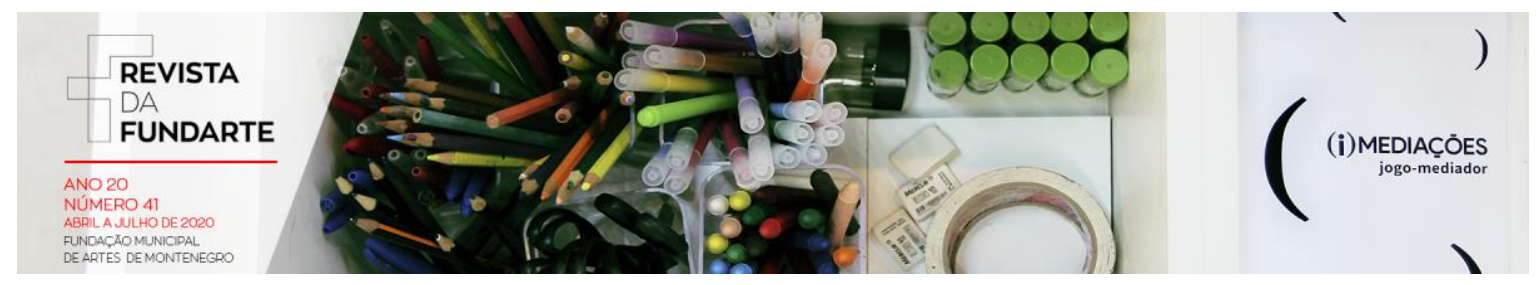

formal de dança, procurando aprofundar reflexões sobre as lacunas entre teoria e prática, ainda persistentes, no acesso e inclusão desse grupo social no fazer da dança.

\section{Metodologia}

Foi realizado uma pesquisa de campo de natureza qualitativa, com utilização de entrevista semiestruturada como instrumento de coleta de dados, no período de dezembro de 2018 à março de 2019. Participaram do estudo 10 pessoas com deficiência e transtornos globais do desenvolvimento, 5 mulheres e 5 homens, na faixa etária entre 18 e 23 anos, praticantes de dança de salão e danças urbanas em uma academia da cidade de Curitiba-PR, com tempo médio de prática de dança de 4 anos e 8 meses. Os critérios de inclusão para os estudantes participantes do estudo foram: ter diagnóstico de deficiência e/ou outras necessidades especiais há pelo menos 2 anos e serem praticantes de dança no contexto de ensino não-formal (academia) há pelo menos 2 anos. Fizeram parte do estudo também 2 professores de dança que atuam com turmas que incluem pessoas com deficiência, com tempo médio de experiência docente neste contexto de 5 anos e 5 meses. Para serem incluídos no estudo, os profissionais deveriam ser professores de dança no ambiente de academias de dança há pelo menos 2 anos.

O estudo foi aprovado pelo Comitê de Ética em Pesquisa - CEP e, após assinaram o termo de consentimento livre e esclarecido, os participantes responderam a uma entrevista semiestruturada com questões relativas a suas percepções sobre acesso e inclusão nos processos de ensino, aprendizagem e criação em dança no ambiente da academia. Os dados foram analisados e contextualizados a partir do conceito de umwelt, proposto por Jacob Von Uexkull, em interface com a abordagem de aprendizagem inventiva proposta por Virginia Kastrup, aplicados à produção de conhecimento em arte/dança.

BERTOLDI, Andrea Lucia Serio; MARQUERITTE, Matheus dos Anjos. Ilhas e tentilhões: o convívio social como estratégia de acesso e inclusão em dança. Revista da FUNDARTE. Montenegro, p.0125, ano 20, no 41, Abril/Junho de 2020.

Disponível em: http://seer.fundarte.rs.gov.br/index.php/RevistadaFundarte/index> 30 de junho de 2020. 


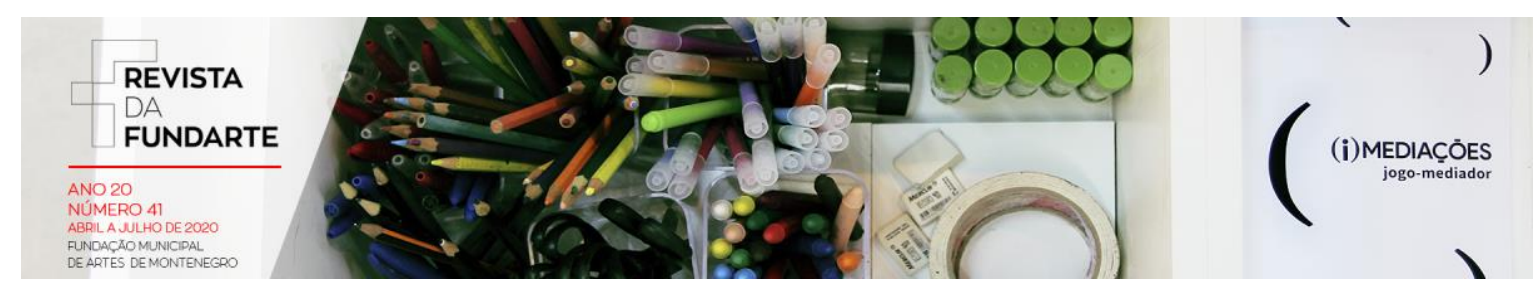

\section{Quebrando muros: os desafios e potências na formação dos professores}

Os resultados das entrevistas realizadas com os dois professores participantes do estudo indicaram que ambos possuem formação acadêmica em nível de graduação, sendo um deles em Educação Física e o outro em Psicologia, e também possuem formação em nível de pós-graduação, com especialização em Educação Especial.

Quando questionados sobre a motivação para atuarem como professores de dança incluindo pessoas com deficiência, os dois professores afirmaram que o interesse surgiu a partir de experiências promovidas pela própria academia onde atuam. Sobre o modo como compreendem o conceito de inclusão em sua experiência, um dos participantes relatou que compreende o conceito relacionado à possibilidade de pessoas com deficiência praticarem dança com profissionais capacitados, enquanto o outro participante afirmou que, em sua percepção do contexto, a inclusão estaria relacionada com a possibilidade de expressão da individualidade dos diferentes corpos.

No que concerne aos referenciais teóricos e artísticos utilizados por esses profissionais para desenvolverem suas aulas, foram citados estudos de Lev Semenovich Vygotsky e a Psicologia histórico-cultural como referências principais, além de autores próprios das modalidades de dança com as quais atuam. Os participantes relataram ainda que atualizam suas práticas por meio de plataformas digitais, principalmente assistindo a vídeos de dança e em cursos de pós-graduação.

Em relação aos objetivos do trabalho desenvolvido nas aulas de dança com estudantes com deficiência, os docentes participantes relataram que o trabalho tem objetivo integral, abrangendo as esferas artística, social e terapêutica. Além disso, os dois professores entrevistados entendem que o papel social da dança é o principal norteador de seus trabalhos.

BERTOLDI, Andrea Lucia Serio; MARQUERITTE, Matheus dos Anjos. Ilhas e tentilhões: o convívio social como estratégia de acesso e inclusão em dança. Revista da FUNDARTE. Montenegro, p.0125, ano 20, no 41, Abril/Junho de 2020.

Disponível em: http://.seer.fundarte.rs.gov.br/index.php/RevistadaFundarte/index> 30 de junho de 2020. 


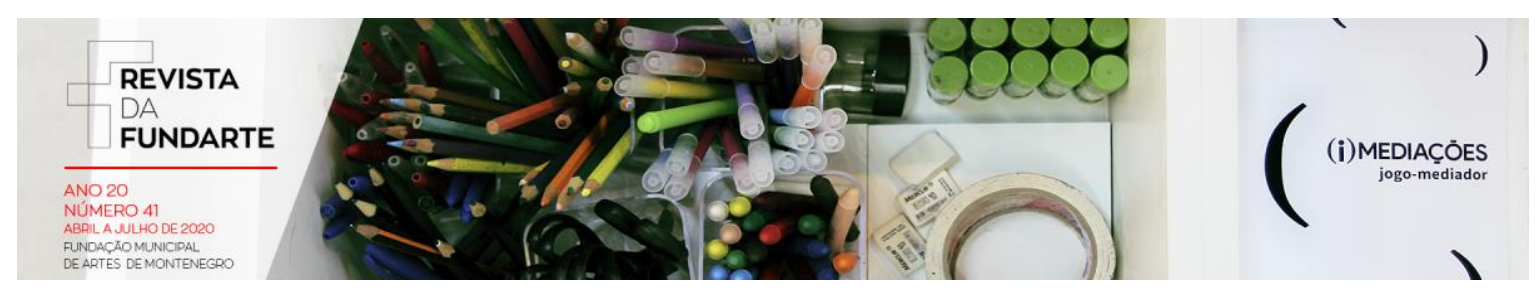

Quando questionados se eles se sentem preparados para atuar incluindo pessoas com deficiência na dança, ambos relataram que sentem-se totalmente preparadas. Em contrapartida, acreditam que a maioria dos profissionais de dança que atua no contexto de academias, não esteja preparada para esta realidade, sobretudo, por falta de oportunidade de experiência prática. No que se refere às abordagens metodológicas por eles adotadas, na instituição de ensino não-formal em que atuam, os professores não identificam uma metodologia específica, mas, destacam que, em geral, lançam mão de estratégias de fragmentação do ensino de passos de dança e buscam a adequação da comunicação com estudantes com deficiência como facilitadores do processo de aprendizagem, como pode ser observado no discurso do professor entrevistado 2:

Então, eu tento quebrar todos os passos... tento deixar os passos, dividir os passos em vários momentos. Então, se o passo tem dois tempos, eu divido em um até chegar no dois... se o passo tem um contratempo, eu pulo o contratempo e depois eu vou incluindo ele. Então eu vou dividindo os passos a cada... dividir o máximo que eu consigo, os passos, para passar para eles e uso várias formas de falar com eles também. (PROFESSOR ENTREVISTADO 2, 2019).

Observamos no depoimento desse participante do estudo, aspectos sobre o ensino da dança de salão que enfatizam o predomínio de estratégias facilitadoras da reprodução de passos de dança. Este tipo de abordagem é comumente verificada em diferentes ambientes de ensino da dança e indica possibilidades de contextualização dessas práticas, considerando o entendimento de que passos de dança codificados ao longo do tempo, nada mais são que a expressão de corpos/pensamentos em um dado contexto histórico e social e não a própria dança (BERTOLDI, 2015).

$\mathrm{Na}$ medida em que a reprodução de códigos originários da expressão de corpos considerados aptos para a dança nortear o desenvolvimento de estratégias

BERTOLDI, Andrea Lucia Serio; MARQUERITTE, Matheus dos Anjos. Ilhas e tentilhões: o convívio social como estratégia de acesso e inclusão em dança. Revista da FUNDARTE. Montenegro, p.0125, ano 20, n -41, Abril/Junho de 2020.

Disponível em: http://.seer.fundarte.rs.gov.br/index.php/RevistadaFundarte/index> 30 de junho de 2020. 


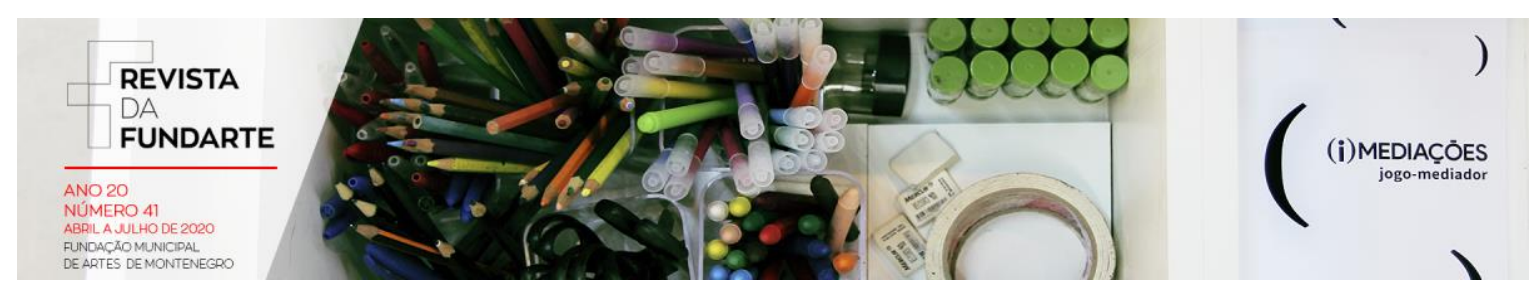

metodológicas de ensino e aprendizagem dessa arte, teremos como consequência uma práxis ancorada na valorização de uma suposta normalidade, o que reduz possibilidades de pertencimento dos discursos próprios dos corpos/pessoas em sua diferença, relegando os que não se enquadram no modelo dado à cultura da adaptação, por vezes confundida com metodologia de ensino e aprendizagem inclusiva na dança (MATOS, 2012; BERTOLDI; SOUZA, 2009).

Esse entendimento se contrapõe à noção de aprendizagem inventiva proposta por Kastrup (2007), e possibilita o questionamento do predomínio do uso de estratégias pedagógicas fundamentadas em uma perspectiva modernista de ensino e aprendizagem na dança, na qual, corpos considerados fora da norma são expostos à adaptação de suas potencialidades, com o propósito de solucionar problemas postos, advindos de questões alheias a seus próprios corpos. $\mathrm{Na}$ modernidade, a cognição e a aprendizagem estiveram atreladas à representação, e a criatividade foi reduzida à capacidade de solucionar problemas, Contrariando essa visão modernista Kastrup (2001) defende que,

[...] uma concepção de aprendizagem inventiva depende da percepção de discordância nas faculdades perceptivas, o que não ocorre na estabilidade da reprodução de conhecimentos, mas na instabilidade da produção de subjetividades, descrita como um aspecto do fenômeno da aprendizagem, que se dá no "encontro de diferenças, num plano de diferenciação mútua, em que tem lugar a invenção de si e do mundo". (KASTRUP, 2001, p. 20).

Desse modo, uma perspectiva inventiva e, portanto, inclusiva de ensino e aprendizagem de dança, demanda experiências que não se apoiam em preceitos de linearidade, estabilidade e previsibilidade de comportamentos, mas, na instabilidade da criação e na invenção como o pressuposto do processo de ensino-aprendizagem. Considerando essa concepção, Kastrup (2001) destaca o papel do professor como um atrator do conhecimento, afirmando que:

BERTOLDI, Andrea Lucia Serio; MARQUERITTE, Matheus dos Anjos. Ilhas e tentilhões: o convívio social como estratégia de acesso e inclusão em dança. Revista da FUNDARTE. Montenegro, p.0125, ano 20, no 41, Abril/Junho de 2020.

Disponível em: http://.seer.fundarte.rs.gov.br/index.php/RevistadaFundarte/index> 30 de junho de 2020. 


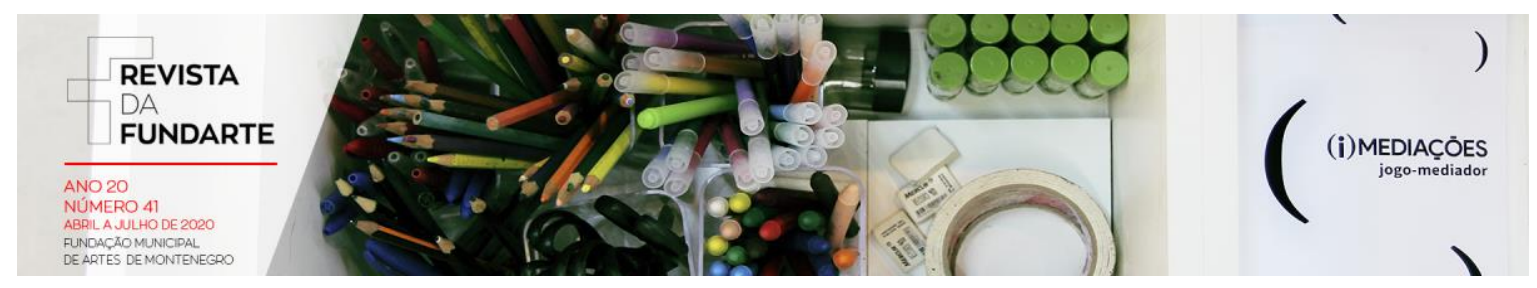

[...] alguém que exerce a função de conduzir o processo, a expedição a um mundo desconhecido, de fazer acontecer o contato, de possibilitar a intimidade, de acompanhar, e mesmo de arrastar consigo, de puxar. Não para junto de si, mas para junto da matéria, para o devir da matéria, seguindo, acompanhando sua fluidez. (KASTRUP, 2001, p. 26).

Para Volp (2010), embora a reprodução de passos de dança e a prática de técnicas de postura e de percepção rítmica se configurem como predomínio cultural no ensino das danças de salão, é necessário considerar os pressupostos que originaram tais danças, para contextualizar suas metodologias de ensino e aprendizagem na contemporaneidade. No caso da dança de salão, o convívio e a interação social motivaram sua origem e são catalisadores dos desdobramentos técnicos nela implícitos, culturalmente transformados e codificados em passos de dança.

O mesmo ocorre no ensino de danças urbanas, sobretudo nas práticas advindas do movimento cultural hip-hop. Originalmente praticada por jovens moradores de comunidades periféricas como forma de resistência às desigualdades sociais, essas danças, mais que passos a serem aprendidos, foram caracterizadas, historicamente, como um lugar de fala (e escuta) de corpos marginalizados em suas vivências singulares (NOVAES, 2002). Portanto, a origem dessas danças está fundamentada no protagonismo da convivência entre as diferenças corporais. Reconhecer esses, entre outros aspectos epistemológicos de manifestações da dança é fundamental para analisar questões metodológicas desenvolvidas no seu ensino, aprendizagem e criação, incluindo corpos fora dos padrões, culturalmente normatizados, como aptos para pertencerem à dança.

Embora as estratégias metodológicas relatadas neste estudo evidenciem o predomínio do ensino adaptado de passos, como prática para incluir pessoas com deficiência, quando analisamos o entendimento do conceito de inclusão descrito pelos participantes, observamos que ele está relacionado à expressão da

BERTOLDI, Andrea Lucia Serio; MARQUERITTE, Matheus dos Anjos. Ilhas e tentilhões: o convívio social como estratégia de acesso e inclusão em dança. Revista da FUNDARTE. Montenegro, p.0125, ano 20, no 41, Abril/Junho de 2020.

Disponível em: http://.seer.fundarte.rs.gov.br/index.php/RevistadaFundarte/index> 30 de junho de 2020. 


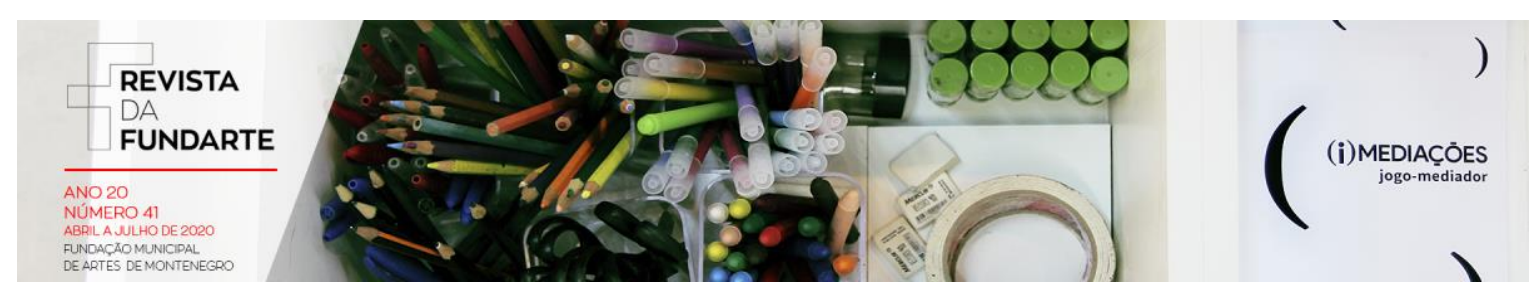

individualidade dos corpos na dança. Este entendimento conceitual é coincidente com pressupostos de procedimentos de dança, que mediam a investigação de movimentos corporais na potencialidade da alteridade (GREINER, 2017), e dialogam com um conceito inventivo de ensino e aprendizagem.

Pensar a inclusão como possibilidade de convívio na diferença coloca em evidência a experiência de subjetivação e pertencimento dos corpos em sua singularidade física, expressiva, criativa e de relação interpessoal. Nesse contexto, para além do ensino de passos, o conceito de inclusão adotado pelos participantes do estudo, parece estar alinhado com práticas que abrem espaços de escuta aos discursos dos diferentes corpos que dançam, o que originalmente caracterizou, tanto as danças de salão como as danças urbanas, particularmente, o hip-hop (VOLP, 2010, NOVAES, 2002).

Outro ponto a ser destacado é o entendimento dos participantes do estudo de que a dança é um espaço social de desenvolvimento integral do ser humano. É possível reconhecer a afinidade deste entendimento conceitual, com procedimentos metodológicos que potencializam o mundo representacional cognitivo dos indivíduos, na especificidade de sua própria experiência corporal, e não na adaptação e subordinação de corpos considerados fora da norma a modelos de corpos tradicionalmente autorizados a pertencer à dança.

$\mathrm{Na}$ medida em que a dança é assumida, teoricamente, em seu potencial de desenvolvimento humano integral, sua prática pressupõe um investimento pedagógico na interface entre a noção de consciência corporificada, estruturada na articulação das experiências subjetivas de pertencimento de todos os corpos ao ambiente em que habitam (LAKOFF; JOHNSON, 1999, DAMÁSIO, 2012) com a fricção da percepção de realidade, decorrente da dilatação do umwelt de cada pessoa (UEXKULL, 1992). Essa articulação reafirma a possibilidade de criação de estratégias metodológicas, que considerem a subjetividade dos corpos e a

BERTOLDI, Andrea Lucia Serio; MARQUERITTE, Matheus dos Anjos. Ilhas e tentilhões: o convívio social como estratégia de acesso e inclusão em dança. Revista da FUNDARTE. Montenegro, p.0125, ano 20, no 41, Abril/Junho de 2020.

Disponível em: http://.seer.fundarte.rs.gov.br/index.php/RevistadaFundarte/index> 30 de junho de 2020. 


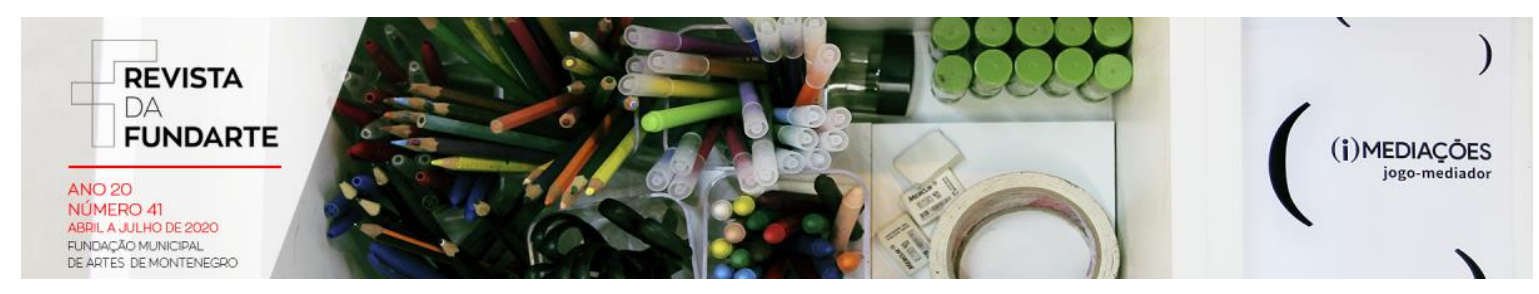

imprevisibilidade de sua interação com 0 ambiente, como potência de desenvolvimento humano integral.

As contradições entre teoria e prática, observadas neste estudo, expõem a urgência da discussão sobre a formação de professores diante da persistência de práticas de reprodução de códigos criados por e para corpos inseridos na norma vigente, ainda que com propósitos e convicções conceituais inclusivos. Parece urgente promover a aproximação entre a dimensão social, cultural e neurobiológica, implícitas na noção de consciência corporificada (LAKOFF; JOHNSON, 1999, HANNA; MAISE, 2009; DAMÁSIO, 2012; MARINIS, 2012) e a experiência inventiva de aprendizagem (KASTRUP,) para a produção de conhecimento artístico.

Apesar dos resultados desse estudo indicarem a necessidade de aproximação entre teoria e prática pedagógica nos processos de ensino e aprendizagem na dança, eles evidenciaram também, uma importante tendência de abertura ao convívio na diferença, em ambientes não formais de ensino de dança, verificada no relato dos professores sobre o incentivo recebido da instituição onde atuam para ministrarem aulas, incluindo pessoas com deficiência. A possibilidade de corpos culturalmente marginalizados adentrarem a esses espaços é um movimento importante e, embora recente, tem exposto desafios a serem enfrentados pela área da dança, considerando os aspectos multidimensionais de perspectivas pedagógicas de acessibilidade e inclusão (SASSAKI, 2005).

Inúmeros professores que ministram aulas de dança em academias possuem formação em nível de graduação e pós-graduação, em áreas que permitem relação com a dança, como no caso dos participantes deste estudo. Porém, é importante considerar que a consolidação da dança como área de conhecimento, demanda o aprofundamento de especificidades próprias desta área, as quais tem fortalecido características de formação de professores de dança na interdependência dos processos de criação-ensino-aprendizagem, como fundamento da atuação do artista-docente (MARQUES, 2014). De acordo com a autora, o artista-docente, ao social como estratégia de acesso e inclusão em dança. Revista da FUNDARTE. Montenegro, p.0125, ano 20, no 41, Abril/Junho de 2020.

Disponível em: http://.seer.fundarte.rs.gov.br/index.php/RevistadaFundarte/index> 30 de junho de 2020. 


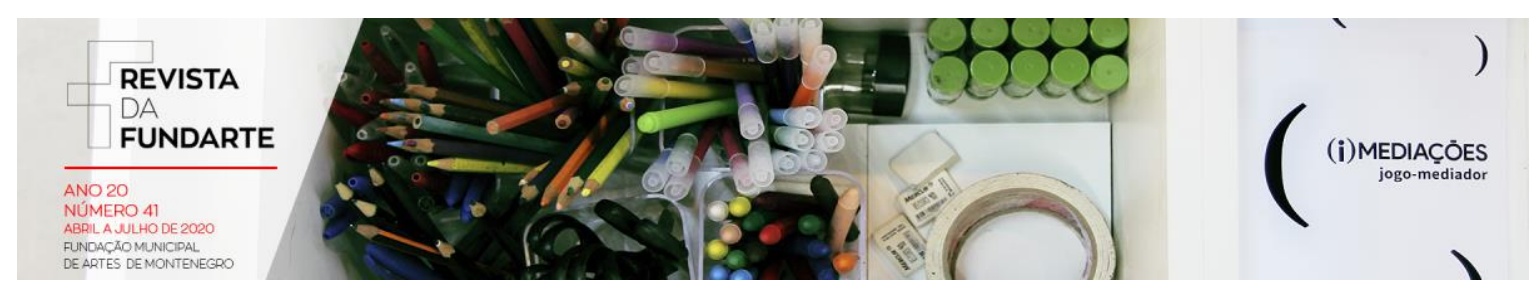

assumir que não transmite conhecimentos, retoma a questão da problematização e da invenção da realidade como eixos da aprendizagem.

Diferentes campos de conhecimento como Arte, Educação, Neurociência Cognitiva, Filosofia, Psicologia, Biologia, entre outros, assumem a necessidade de reconfiguração das fronteiras entre corpo, mente e ambiente, no fenômeno da aprendizagem e enfatizam o papel central da experiência corporal nas relações entre as emoções, sentimentos e a organização de redes de conexões neurocerebrais, criadas nos sistemas de memória, cognição, atenção e percepção (DAMÁSIO, 2011; ALMADA; MESQUISTA, 2017). Nesta perspectiva, Kastrup, (2001) destaca a relevância da noção de pertencimento dos corpos para a ação de aprender, a partir de um viés ecossistêmico, afirmando que:

Através da aprendizagem de semióticas locais e específicas são configuradas fronteiras de conexão com o ambiente. Ao falar de semióticas que são formadas ao longo de um processo de aprendizagem, falamos de uma aprendizagem territorial. (KASTRUP, 2001, p. 22).

Compreender processos artístico-educacionais em dança pelo viés do pertencimento territorial e da invenção, indica perspectivas de atualização de metodologias interdependentes de ensino-aprendizagem-criação em dança, pautadas no exercício da alteridade, na produção de subjetividades e na fricção do convívio humano na diferença (GREINER, 2017). Neste contexto, ainda que as interações entre áreas seja uma condição da produção de conhecimento humano diante de sua característica de complexidade, parece não haver lugar para a noção de território homogeneizado, como ambiente propício para o ensino e aprendizagem em dança, considerando a possibilidade de pertencimento dos diferentes corpos que dançam.

A aproximação entre conceitos de validação da diferença e o fazer pedagógico da dança pode representar um caminho efetivo em direção à quebra de

BERTOLDI, Andrea Lucia Serio; MARQUERITTE, Matheus dos Anjos. Ilhas e tentilhões: o convívio social como estratégia de acesso e inclusão em dança. Revista da FUNDARTE. Montenegro, p.0125, ano 20, no 41, Abril/Junho de 2020.

Disponível em: http://.seer.fundarte.rs.gov.br/index.php/RevistadaFundarte/index> 30 de junho de 2020. 


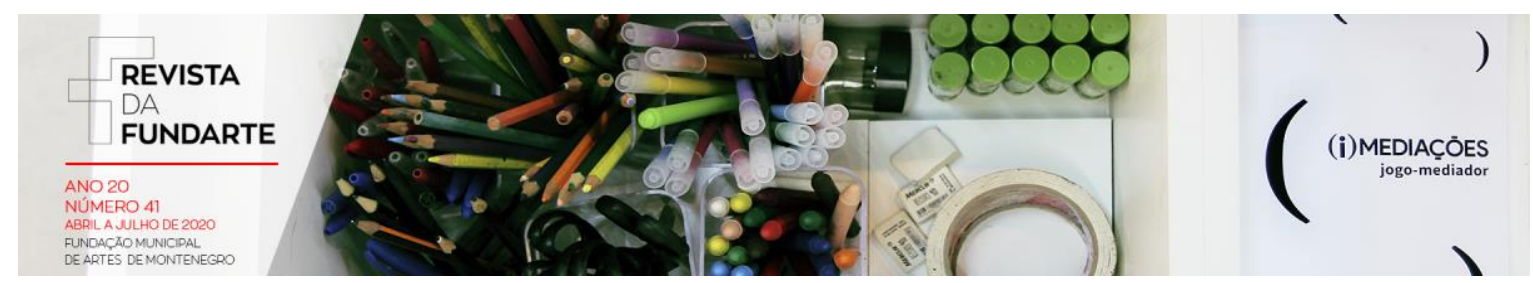

muros paternalistas que ainda permeiam a cultura da prática de inclusão de pessoas com deficiência na dança, e mantém mecanismos de dominação social de modelos de corpos/movimentos, sobre a especificidade da experiência corporal, contrariando sua potência como manifestação artística, inerentemente inclusiva.

\section{Tentilhões de Darwin: o convívio social e a noção de pertencimento}

Professores e alunos foram questionados sobre os principais impactos positivos que percebem com a prática da dança e, sobre esta questão, $70 \%$ dos alunos e os dois professores entrevistados citaram a socialização como o maior benefício percebido por eles. Os outros impactos positivos citadas pelos alunos foram os benefícios ao corpo (40\%) e a oportunidade de novos aprendizados (10\%).

A percepção de que a socialização é o maior impacto positivo da prática da dança pode ser observada no discurso de um dos alunos entrevistados, que ilustrou sua resposta afirmando que "é bom para a gente dançar. É muito importante para nós... porque nossos amigos estão lá, cheios de alegria... para nós...nossos amigos e os professores que ensinam a gente a dançar..." (ALUNO ENTREVISTADO 1, 2019). Em consonância com essa percepção de importância da convivência social relatada pela maioria dos alunos, um dos professores entrevistados ressalta:

[...] eu acho que é o impacto da questão da socialização, porque de fato eles desenvolvem um grupo de interesse comum, porque aí eles estão entre os pares deles. Então, essas relações tipo namoro, amizade... eles desenvolvem um vínculo que faz com que eles façam atividades juntos, fora, e cada vez mais atividades. Então, eu acho que esse é o impacto mais positivo de todos né? (PROFESSOR ENTREVISTADO 1, 2018).

Em contrapartida, quando os estudantes foram questionados sobre seu interesse em participar de experiências em dança, como apresentações e aulas fora de sua própria turma, na academia em que fazem aula, 60\% afirmaram que não

BERTOLDI, Andrea Lucia Serio; MARQUERITTE, Matheus dos Anjos. Ilhas e tentilhões: o convívio social como estratégia de acesso e inclusão em dança. Revista da FUNDARTE. Montenegro, p.0125, ano 20, no 41, Abril/Junho de 2020.

Disponível em: http://seer.fundarte.rs.gov.br/index.php/RevistadaFundarte/index> 30 de junho de 2020. 


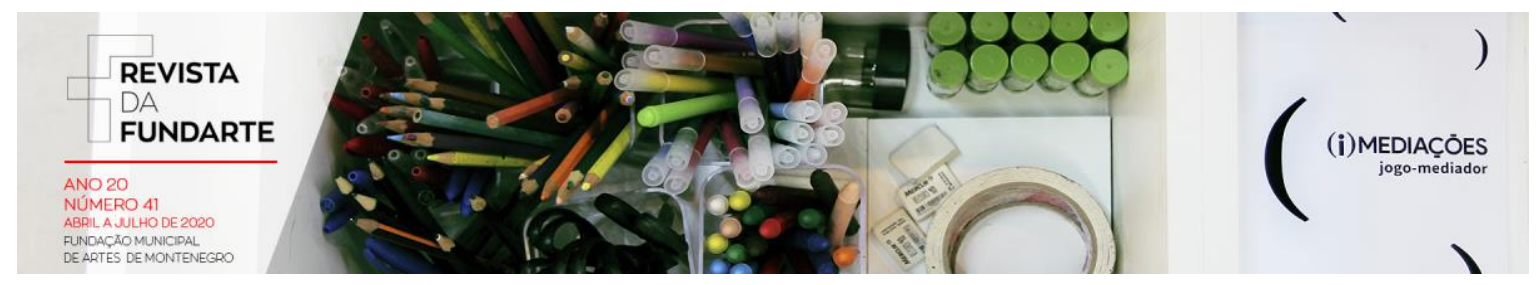

possuem interesse em participar de outras experiências externas à escola, e os demais (40\%) não souberam responder. Quando questionados se já possuíam alguma vivência na participação em aulas de dança ou apresentação em outro local, $60 \%$ do grupo de alunos disseram nunca ter tido essa experiência. Os estudantes foram questionados também sobre suas motivações para a prática da dança e, entre as respostas, destacaram o entretenimento (50\%) e a influência dos familiares (30\%) como os principais eixos, enquanto $10 \%$ afirmaram a possibilidade de se tornarem artistas da dança e 10\% não souberam responder.

É curioso notar que, se por um lado os entrevistados (professores e alunos) entendem que a socialização é o maior benefício da prática da dança $(70 \%$ dos alunos e $100 \%$ dos professores) por outro, não verificamos esse aspecto evidenciado no interesse desses alunos em ocuparem seus espaços como artistas em outras turmas de dança - que não aquelas específicas para pessoas com deficiência dentro da academia - ou em outros espaços onde a dança é desenvolvida.

Ainda que essa característica possa se relacionar com o tipo de motivação desses estudantes para a prática da dança, é importante analisar possíveis relações com o desenvolvimento da noção de pertencimento desses corpos à dança, restrito ao convívio entre "iguais", e não às diferenças no âmbito do ensino e aprendizagem da dança. Este fato pode ser verificado, não apenas na composição de turmas especiais em ambientes de ensino não-formal da dança, como no caso estudado, mas na criação de danças e eventos de arte especiais, verificados ao longo dos últimos trinta anos no Brasil e em vários países, exclusivos para pessoas com deficiência, ironicamente chamados de inclusivos (MATOS, 2012; SÉRIO; VIEIRA; VIEIRA, 2017).

Embora a criação de eventos exclusivos para um grupo específico de pessoas represente um movimento de visibilidade e de desmobilização do isolamento desse grupo, é preciso reconhecer que, no caso da presença de corpos social como estratégia de acesso e inclusão em dança. Revista da FUNDARTE. Montenegro, p.0125, ano 20, no 41, Abril/Junho de 2020.

Disponível em: http://.seer.fundarte.rs.gov.br/index.php/RevistadaFundarte/index> 30 de junho de 2020. 


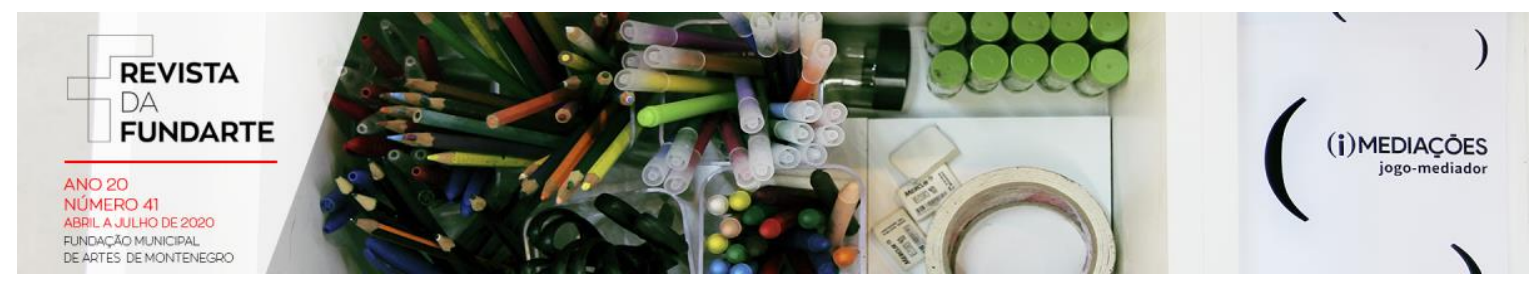

com deficiência na dança, embora estes eventos especiais tenham possibilitado reflexões importantes sobre inclusão/exclusão, a produção de discursos ao longo do tempo ainda não conseguiu se estabelecer como prática de alteridade na arte da dança (BERTOLDI; SOUZA, 2009). Na opinião dos autores, a insistência em separar pessoas com deficiência em territórios específicos de pertencimento autorizado, indica a contraditória coexistência entre a oportunidade de encontros para o avanço de concepções inclusivas na arte e a perversa estruturação silenciosa de mecanismos ocultos de dominação e exclusão social da diferença, consolidados na própria delimitação dos territórios de pertencimento.

Desde o advento dos estudos promovidos por Charles Darwin a respeito da seleção natural como processo intrínseco à evolução das espécies, muitos foram os progressos científicos que identificaram os mecanismos envolvidos na adaptação dos seres vivos relacionados à delimitação de espaços ou territórios. O destaque do estudo realizado pelo naturalista consiste na relação feita entre as diferenças morfológicas em espécies de tentilhões e a sua localização geográfica no conjunto de ilhas de Galápagos: o tamanho dos bicos das aves variava de acordo com o local em que essas espécies habitavam, pois os alimentos disponíveis também mudavam conforme a geografia.

Posteriormente, outras pesquisas como a de Johnston e Selander (1971, apud. RIDLEY, 2006), trouxeram à tona o estudo da genética de populações correlacionada ao isolamento geográfico e notaram que, quando impõe-se limites regionais, os seres vivos tendem a passar por um processo denominado especiação e a longo prazo, diminuem a variabilidade genética intraespecífica. Em outras palavras, essa visão ambientalista evidenciou que, em condição de isolamento, a taxa de comunicação (ou fluxo de informações) entre a própria espécie decai gradativamente podendo ser prejudicial, inclusive, para a manutenção da vida.

Observamos uma possibilidade de analogia entre os resultados deste estudo, os mecanismos de adaptação verificados nos tentilhões das ilhas de Galápagos e o

BERTOLDI, Andrea Lucia Serio; MARQUERITTE, Matheus dos Anjos. Ilhas e tentilhões: o convívio social como estratégia de acesso e inclusão em dança. Revista da FUNDARTE. Montenegro, p.0125, ano 20, no 41, Abril/Junho de 2020.

Disponível em: http://.seer.fundarte.rs.gov.br/index.php/RevistadaFundarte/index> 30 de junho de 2020. 


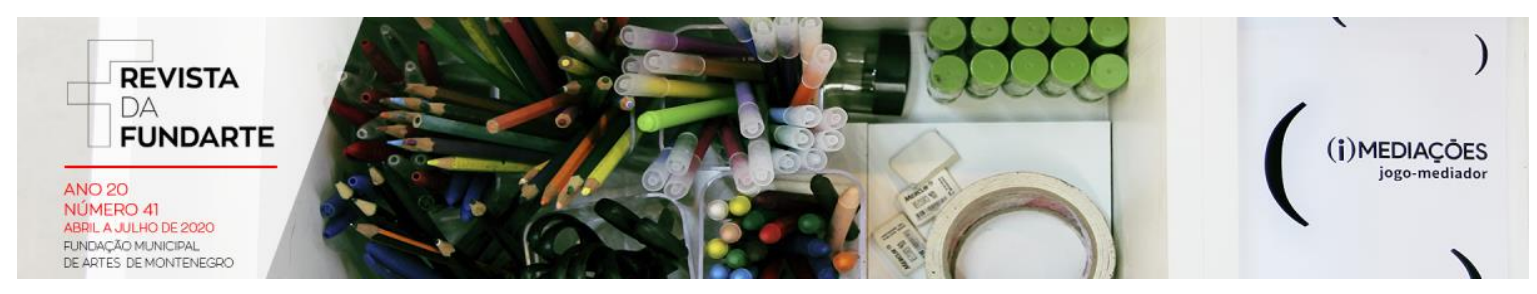

conceito de umwelt (UEXKULL, 1992), no que concerne à interface perceptiva entre seres vivos e o meio. Como coloca Vieira (2006), essa interface, no caso dos seres humanos, extrapola o viés biológico e agrega o ponto de vista psíquico, social e cultural, determinando a elaboração do sistema cognitivo e a forma com que nos tornamos sensíveis à realidade. De forma análoga, o fato da convivência social ser reconhecida neste estudo, como o maior benefício da prática da dança para a maioria dos entrevistados (alunos e professores), enquanto a maior parte dos estudantes relatou desinteresse em ocupar seus espaços fora de turmas especiais de dança, evidencia a complexidade dessa interação biológica, psíquica, social e cultural, no desenvolvimento da noção de pertencimento, diante do isolamento histórico desses corpos na dança.

A noção de pertencimento social de pessoas com deficiência tem sido expandida desde a reorientação do modelo médico de deficiência para o modelo social, que realocou a perspectiva do corpo com deficiência, como pensamento simbólico e político em sua identidade (GOLDMAN, 1999; LE BRETON, 2006). Um dos impactos deste modelo foi o reconhecimento de que as experiências de opressão, cerceadoras de autonomia, comumente vivenciadas pela pessoa com deficiência, não estariam centralizadas na diferença corporal, mas na estrutura social incapaz de responder à diferença como condição do humano.

Os resultados deste estudo indicam que a relação de pertencimento social da pessoa com deficiência à dança é fortemente influenciada pela perspectiva de reprodução de modelos de corpo e movimento, os quais reforçam uma noção de adaptação vinculada à correção, que alimenta a ideia de existência de uma realidade preexistente a ser percorrida, influenciada pela noção de reabilitação dominante no modelo médico de deficiência (GOLDMAN, 1999). Não se pode negar que em função dos avanços conceituais advindos do modelo social de deficiência, a noção de pertencimento social tem sido tensionada, de modo que a autonomia da pessoa com deficiência vem ganhando espaço de pertencimento, especialmente sob

BERTOLDI, Andrea Lucia Serio; MARQUERITTE, Matheus dos Anjos. Ilhas e tentilhões: o convívio social como estratégia de acesso e inclusão em dança. Revista da FUNDARTE. Montenegro, p.0125, ano 20, n -41, Abril/Junho de 2020.

Disponível em: http://.seer.fundarte.rs.gov.br/index.php/RevistadaFundarte/index> 30 de junho de 2020. 


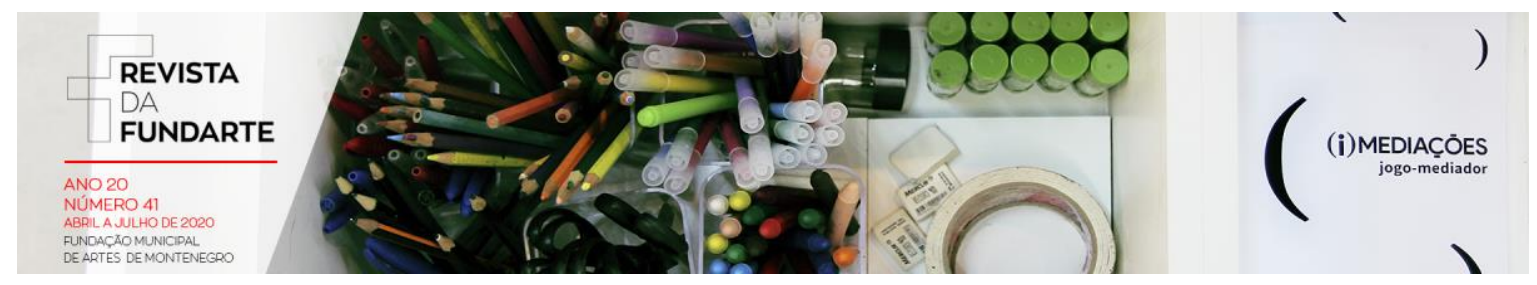

o aspecto das conquistas de direitos. Entretanto o pressuposto aqui é o entendimento de que estas relações sociais entre corpo com deficiência e a noção de pertencimento à dança, atuam como um regime de subjetivação da corporeidade.

Regimes ou nexos de subjetivação do corpo são gerados por experiências socialmente construídas, pelas quais os seres humanos se reconhecem como indivíduos de pertencimento (GOLDMAN, 1999). A pessoa com deficiência, ao ser exposta a relações de ensino e aprendizagem em dança, é um corpo contaminado, isto é, subjetivado em função de sua percepção singular da experiência vivida. Portanto, embora tenha havido um salto conceitual entre os modelos médico e social, principalmente com o ganho do reconhecimento das subjetividades implicadas na construção da noção de direito ao pertencimento social da pessoa com deficiência, os resultados deste estudo indicam a persistência de relações de ensino e aprendizagem da dança, que privilegiam a dominação de uma realidade preexistente, limitada na experiência de investigação dos corpos em suas singularidades e, portanto, limitada nas dimensões possíveis de pertencimento à dança pela experiência de expansão da realidade que caracteriza a arte (VIEIRA, 2006).

Segundo Lepeck (2003), inúmeros artistas e professores de dança tem colaborado com a reinvenção de novos mapeamentos dos corpos em sua identidade e pertencimento social, entretanto assim como observado nos resultados deste estudo, o autor destaca que ainda há contradições importantes onde a dança estaria titubeante na validação de um pensamento/ação pautado na alteridade. Esse modo titubeante de reconhecimento da diversidade dos corpos/pensamentos, é exemplificado nas danças multiculturais ou globais que, segundo Lepeck (2003) foram submetidas à comercialização e estetização de tal ordem que as mantém aprisionadas na estética do exótico e na contemplação à distância.

Concordando com esse ponto de vista, Bertoldi (2015) afirma que, igualmente titubeante está a dança que insiste em estabelecer um modo particular de social como estratégia de acesso e inclusão em dança. Revista da FUNDARTE. Montenegro, p.0125, ano 20, n -41, Abril/Junho de 2020.

Disponível em: http://seer.fundarte.rs.gov.br/index.php/RevistadaFundarte/index> 30 de junho de 2020. 


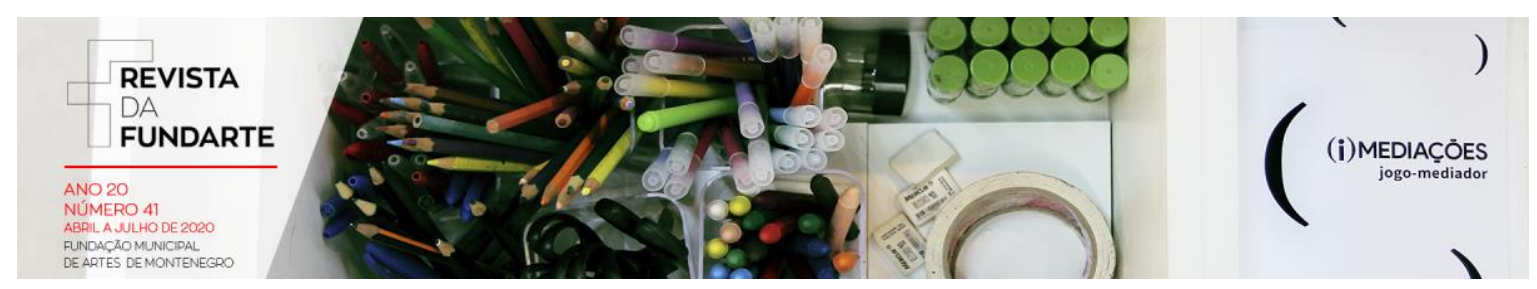

pertencimento do corpo com deficiência, autorizado a estar nos espaços de dança, desde que, com a devida distância que lhe é conferida.

Ao negar a particularidade da subjetividade do corpo com deficiência, por natureza provocador, capaz de acionar em nós percepções sobre nossa própria fragilidade de pensamento/atitude, o discurso de que todos os corpos são distintos, diferentes, todos temos deficiências, toma um lugar perigoso. Dependendo de mudanças muito sensíveis no modo de entender a relação de diferentes corpos com a autonomia, as "autorizações" de pertencimento tornam-se algemas porque deixam de ser possibilidades de apropriação e passam a constituir o discurso ocultamente opressor de subjetividades, criando lenta e silenciosamente o crivo do corpo aceito, pertencente, autorizado a escolher como quer estar na dança. (BERTOLDI, 2015, p. 37).

A falta de autonomia de corpos socialmente marginalizados na dança reafirmam a existência de ilhas de conhecimento que moldam determinados comportamentos no fazer desta arte, semelhantes às ilhas de Galápagos onde os tentilhões de Darwin habitavam. Embora a persistência do isolamento de estudantes com deficiência não seja absoluto, sob o ponto de vista geográfico (visto que eles se inserem em outros ambientes além-academia de dança) como o das aves, a criação de turmas, danças e eventos específicos para pessoas com deficiência em todo o mundo, naturaliza uma noção de convivência higienista e pode explicar posturas passivas de desinteresse pela ocupação de outros espaços, fora de nichos, ou ilhas de pertencimento autorizado. Esse contexto, indica a urgência da aproximação entre os discursos e as práticas pedagógica para o convívio dos diferentes corpos que dançam, considerando que, pessoas com deficiência adentram o ambiente de ensino não-formal da dança, mas por hora, não se apropriam integralmente desses espaços como corpos autônomos para o livre pertencimento à dança.

BERTOLDI, Andrea Lucia Serio; MARQUERITTE, Matheus dos Anjos. Ilhas e tentilhões: o convívio social como estratégia de acesso e inclusão em dança. Revista da FUNDARTE. Montenegro, p.0125, ano 20, no 41, Abril/Junho de 2020.

Disponível em: http://.seer.fundarte.rs.gov.br/index.php/RevistadaFundarte/index> 30 de junho de 2020. 


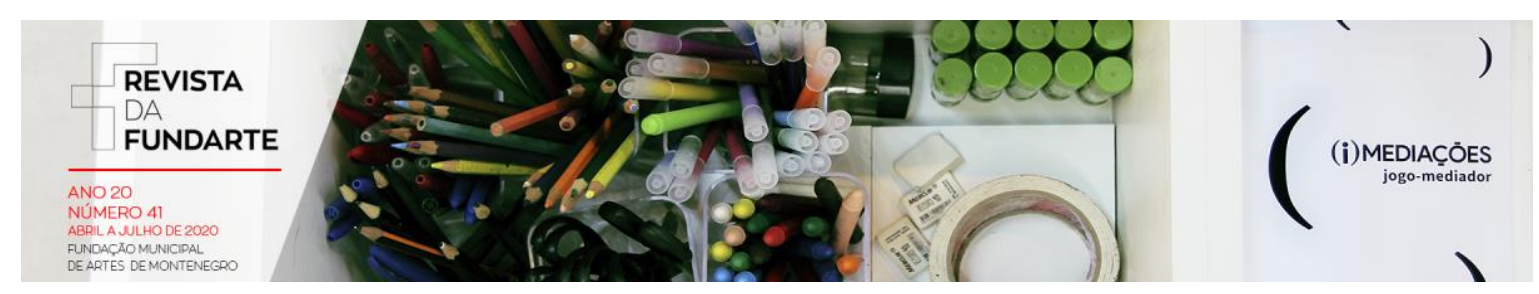

\section{Considerações Finais}

Os resultados desta pesquisa indicam que pessoas com deficiência estão ocupando espaços de desenvolvimento da dança em ambientes não-formais de ensino, como as academias. Este espaço, porém, ainda parece estar restrito a turmas exclusivas para este grupo de pessoas. A procura por aulas de dança de salão e danças urbanas é motivada pelo entretenimento e a socialização é relatada pelos participantes como o impacto mais importante da prática da dança em suas vidas. Entretanto, esses estudantes não percebem como um fator importante para si, a ocupação de outros espaços sociais de produção da dança, que não o das turmas específicas para pessoas com deficiência.

Os professores entrevistados concordam com os estudantes, no que se refere à socialização ser o principal impacto da prática da dança, e afirmam que suas práticas pedagógicas tem um propósito integral, incluindo aspectos artísticos, sociais e terapêuticos. Citam, como estratégias metodológicas de trabalho inclusivo, procedimentos de facilitação do ensino de passos específicos de dança para esse grupo de pessoas, no contexto das turmas em que atuam.

O entendimento de que a dança é uma arte que considera a potência da convivência da diferença dos corpos, estabelece sua condição inerentemente inclusiva e indica a necessidade de atualização da formação de professores de dança na interdependência dos processos de criação-ensino-aprendizagem. Dessa forma, a perspectiva de um pensamento de corpo e aprendizagem não caracterizada pelo acúmulo de estratégias de soluções de problemas, mas pela experimentação e compartilhamento de singularidades corporais na problematização da realidade, pode ampliar a noção de ensino fundamentado em passos específicos de dança, e facilitar a retomada de preceitos originários de danças ancoradas no lugar de fala e escuta dos discursos próprios dos corpos em suas diferenças. Nesse sentido, as especificidades da formação do artista-docente pode realocar a problematização e a

BERTOLDI, Andrea Lucia Serio; MARQUERITTE, Matheus dos Anjos. Ilhas e tentilhões: o convívio social como estratégia de acesso e inclusão em dança. Revista da FUNDARTE. Montenegro, p.0125, ano 20, no 41, Abril/Junho de 2020.

Disponível em: http://seer.fundarte.rs.gov.br/index.php/RevistadaFundarte/index> 30 de junho de 2020. 


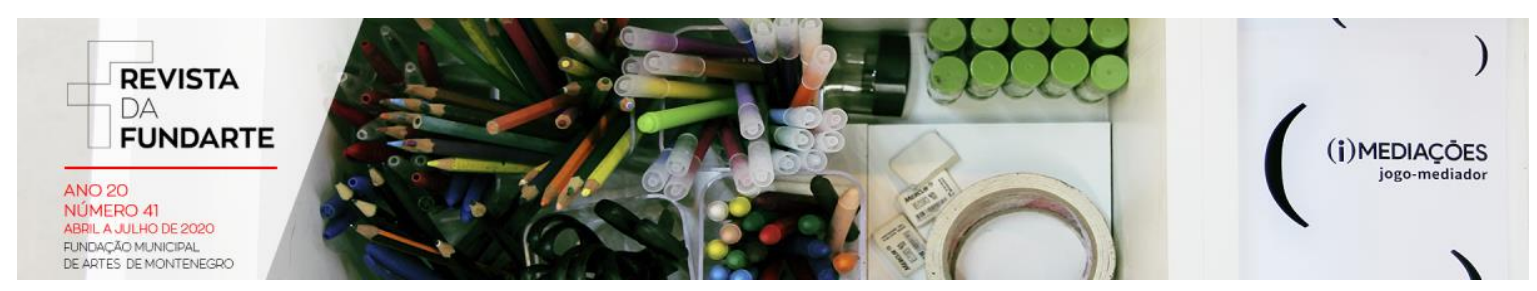

invenção para o centro da aprendizagem e apontar caminhos de aproximação das lacunas observadas entre teoria e prática da dança, necessárias à validação estética, política e social da diferença dos corpos nesta arte.

Por fim, na medida em que estamos vivendo todos, a experiência corporal de isolamento social em função da pandemia de COVID-19, pensamos ser importante pontuar que os resultados deste estudo podem indicar neste momento histórico, uma abertura à reflexão empática sobre a persistência do isolamento social, como condição naturalizada de vida de pessoas pertencentes a grupos marginalizados, como é o caso de pessoas com deficiência. Essas pessoas tem sido expostas a relações que mimetizam uma espécie de quase inclusão, e impedem a validação política da diferença dos corpos, reforçando mecanismos de subjetivação individual e dominação social que se configuram em barreiras para o pertencimento à dança. Entre ilhas e tendilhões, a dança, assim como os estudos ambientalistas sobre a evolução das espécies, reafirma na urgência da noção de pertencimento social da diferença, mais que na proximidade física dos corpos, uma estratégia de evolução humana e preservação da vida.

\section{Referências:}

ALMADA, Leonardo Ferreira; MESQUITA, Luiz Otávio de Sousa. Corpo, cérebro e ambiente: o organismo como alicerce da mente consciente. Kínesis, Santa Maria, v. 9, n. 21, p.105-125, 2017.

BERTOLDI, Andrea Lúcia. Sério; SOUZA, Claudia Fantin de. Dança inclusiva e o efeito borboleta. Revista da Faced, UFBA, Salvador, v.1 n. 16, p.51-62, 2009.

BERTOLDI, Andrea Lúcia. Sério. Trans(ações) de corpos com deficiência em processos de criação em dança entre otras cositas más. Caderno de Ensaios TOM , UFPR, Curitiba: UFPR, v. 2, p.28-41, 2015. social como estratégia de acesso e inclusão em dança. Revista da FUNDARTE. Montenegro, p.0125, ano 20, no 41, Abril/Junho de 2020.

Disponível em: http://.seer.fundarte.rs.gov.br/index.php/RevistadaFundarte/index> 30 de junho de 2020. 


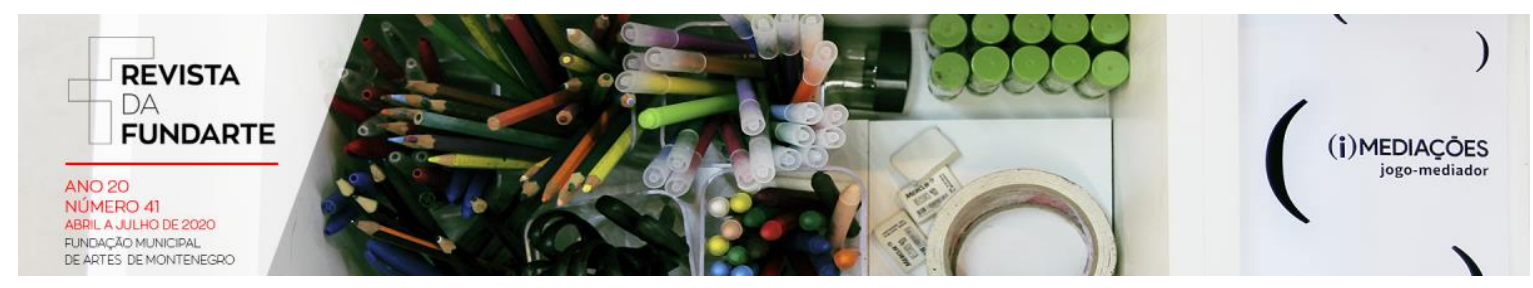

BERTOLDI, Andrea Lúcia. Sério; KUNIFAS, Cinthia. Sobre guarda-chuvas em tempos de ventania: a educação/arte/terapia somática diante de uma epistemologia sistêmica do corpo que dança. Revista Científica, FAP, Curitiba, v.13 n. 13, p.111117, 2015.

BERTOLDI, Andrea Lúcia. Sério; RIL, Aline Ferreira. Aproximações entre neurociências e processos de fruição e criação em dança na infância. In: VELLOZO, M.; STECZ, S. (org.) Criação, ensino e produção de conhecimento em artes: artes visuais, cinema, dança e teatro. Centro de Artes da Universidade Estadual do Paraná - Campus de Campo Mourão: Felcicam, 2016.

DAMÁSIO, António Rosa. E o cérebro criou o homem. Tradução: Laura Teixeira Motta, São Paulo: Companhia das Letras, 2011.

O erro de Descartes: emoção, razão e o cérebro humano. Tradução: Dora Vicente e Georgina Segurado, São Paulo: Companhia das Letras, 2012.

GOLDMANN, Marcio. Uma categoria do pensamento antropológico: a noção de pessoa. In: GOLDMANN, Marcio. Alguma Antropologia. Rio de Janeiro, Relume Dumará: Núcleo de Antropologia da Política, p. 85-109, 1999.

GREINER, Christine. Em busca de uma metodologia para analisar a alteridade na arte. Concept, Campinas, v.6, n.2, p.10-21, jul./dez. 2017.

HANNA, Robert; MAIESE Michelle. Embodied minds in action. Londres: Oxford University Press, 2009.

KASTRUP, Virgínia. Aprendizagem, arte e invenção. Psicologia em Estudo. Maringá, v.6, n.1, p. 17-27, jan./jul. 2001.

Políticas cognitivas na formação do professor e o problema do devirmestre. Educação e Sociedade, Campinas, v. 26, n. 93, p.1273-1288, set./dez. 2005.

A invenção de si e do mundo. Belo Horizonte: Autêntica, 2007.

A atenção na experiência estética: cognição, arte e produção de subjetividade. Trama Interdisciplnar. São Paulo, Universidade Presbiteriana Mackenzie (UPM), v.3, n.1, p. 23-33, 2012.

BERTOLDI, Andrea Lucia Serio; MARQUERITTE, Matheus dos Anjos. Ilhas e tentilhões: o convívio social como estratégia de acesso e inclusão em dança. Revista da FUNDARTE. Montenegro, p.0125, ano 20, no 41, Abril/Junho de 2020.

Disponível em: http://.seer.fundarte.rs.gov.br/index.php/RevistadaFundarte/index> 30 de junho de 2020. 


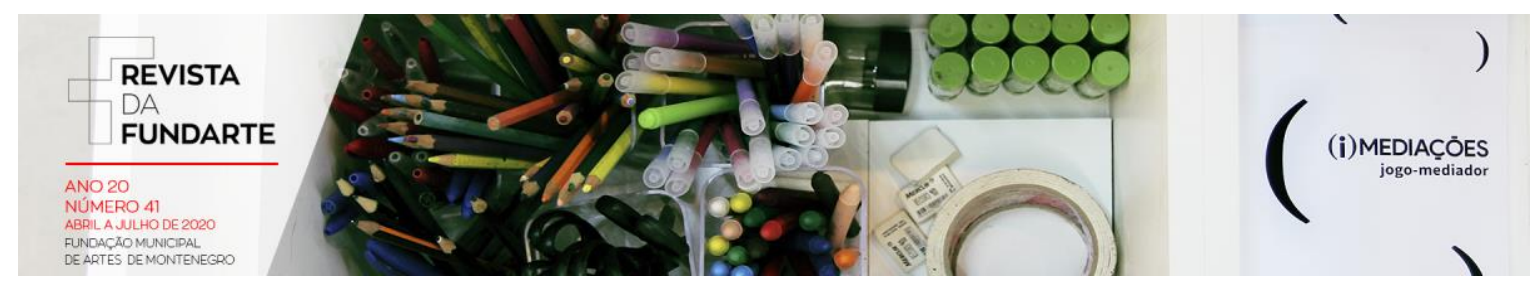

LAKOFF, George; Mark JOHNSON. Philosophy in the flesh: the embodied mind and its challenge to western thought. New York: Basic Books, 1999.

LE BRETON, David. A Sociologia do corpo. Petrópolis, RJ: Vozes, 2006.

LEPECKI, André. O corpo colonizado. GESTO: Revista do Centro Coreográfico do Rio, Rio de Janeiro, vol. 3, n. 2, p. 7-11, jul. 2003.

MARINIS, Marco de. Corpo e corporalidade no teatro: da semiótica à neurociência: pequeno dicionário interdisciplinar. Revista Brasileira de Estudos da Presença, Porto Alegre, v. 2, n. 1, p.42-61, jan./jul. 2012.

MARQUES, Isabel. O artista/docente: ou o que a arte pode aprender com a educação. Ouvirouver, UFMG, Uberlândia, v.10, n.2, p. 230-239, jul./dez. 2014.

MATOS, Lúcia. Corpos que dançam: diferença e deficiência. Revista Diálogos possíveis. Salvador, FSBA, v.1, p.177-185, jul./dez. 2002.

. Dança e diferença: cartografia de múltiplos corpos. Salvador: Editora da Universidade Federal da Bahia - EDUFBA, 2012.

MATURANA, Humberto; VARELA, Francisco. A árvore do conhecimento: as bases biológicas do entendimento humano. Campinas, SP: Psy II, 1995.

NOVAES, Regina. Hip Hop: o que há de novo?. In: BUARQUE, Cristina et. al. (org.). Perspectivas de gênero: debates e questões para ONGs. Recife: GT Gênero Plataforma de Cotrapartes Novib / SOS Corpo e Cidadania, p.110-136, 2002.

REIS, Marlene Barbosa de Freitas. Diversidade e inclusão: desafios emergentes na formação docente. Revelli, UEG, Inhumas, v.8 n.1, p. 1-18, abr. 2016.

RIDLEY, Mark. Evolução. Porto Alegre: Artmed, 2009.

SASSAKI, Romeo Kazumi. Inclusão: o paradigma do século 21. Revista Brasileira de Educação Especial, Brasília, ano 1, n.1, p. 19-23, out. 2005.

SÉRIO Andréa; VIEIRA, Cayo; VIEIRA, Sergio. Corpo em questão. Curitiba: Nó movimento em rede, 2017.

BERTOLDI, Andrea Lucia Serio; MARQUERITTE, Matheus dos Anjos. Ilhas e tentilhões: o convívio social como estratégia de acesso e inclusão em dança. Revista da FUNDARTE. Montenegro, p.0125, ano 20, no 41, Abril/Junho de 2020.

Disponível em: http://.seer.fundarte.rs.gov.br/index.php/RevistadaFundarte/index> 30 de junho de 2020. 


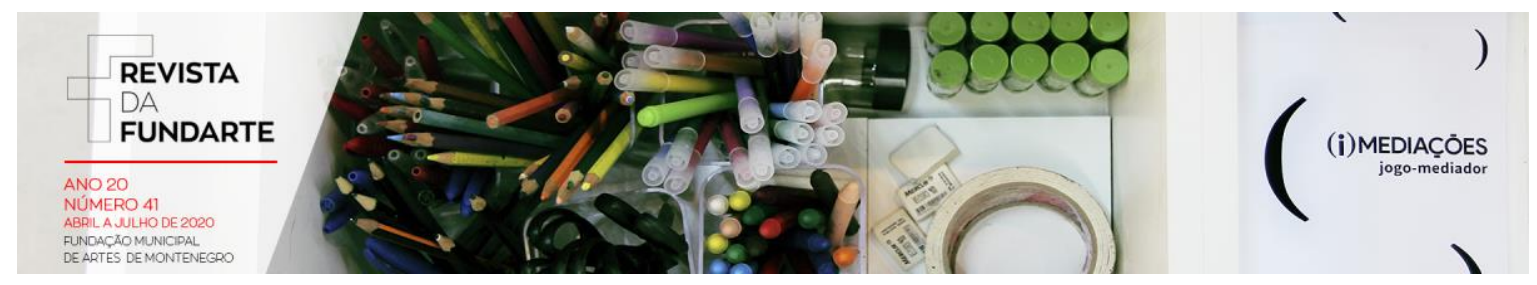

UEXKULL, Jacob von. A stroll though the words of animals and men: a picture book of invisible words. Semiótica. v. 89, n. 4, p. 319-391, 1992.

VIEIRA, Jorge Albuquerque. Teorias do conhecimento e arte: formas de conhecimento - arte e ciência uma visão a partir da complexidade. Fortaleza: Expressão Gráfica, 2006.

VOLP, Catia Mary. A dança de salão como um dos conteúdos de dança na escola. Motriz, Unesp, Rio Claro, v.16 n.1, p. 215-220, jan./mar. 2010.

BERTOLDI, Andrea Lucia Serio; MARQUERITTE, Matheus dos Anjos. Ilhas e tentilhões: o convívio social como estratégia de acesso e inclusão em dança. Revista da FUNDARTE. Montenegro, p.0125, ano 20, no 41, Abril/Junho de 2020.

Disponível em: http://.seer.fundarte.rs.gov.br/index.php/RevistadaFundarte/index> 30 de junho de 2020. 